\title{
EFFECT OF PLAYING METHODS ON THE DRIBBLE ABILITY OF THE FOOTBALL GAME
}

\author{
Alan Alfiansyah Putra Karo Karo ${ }^{1 *}$, Benny Aprial${ }^{2}$, Ika Endah Puspita Sari ${ }^{\text {, Hardodi }}$ \\ Sihombing ${ }^{4}$ Liliana Puspa Sari ${ }^{5}$
}

${ }^{12345}$ Sekolah Tinggi Olahraga dan Kesehatan Bina Guna, Medan, Indonesia

\begin{tabular}{|c|c|}
\hline Info $A$ & Abstract \\
\hline $\begin{array}{l}\text { Article History: } \\
\text { Received September } 2020 \\
\text { Revised September } 2020 \\
\text { Accepted September } 2020 \\
\text { Available online September } 2020\end{array}$ & $\begin{array}{l}\text { This research was motivated by the low level of dribble skills in the } \\
\text { game of football in class VIII students of Budi Agung Private } \\
\text { Junior High School, Medan. Based on this, the research objective } \\
\text { was to determine the effect of playing methods on the dribbling } \\
\text { ability of soccer games. The population and sample studied in this } \\
\text { study were } 30 \text { students and the sample was taken using total } \\
\text { sampling. This research is a field experiment research and the } \\
\text { design of this study used a pre test post test group design. From the } \\
\text { research results, it can be seen that the significance (0.010) is } \\
\text { smaller than } 0.05 \text { and the t-test result ( } 2.739) \text { is greater than the t- } \\
\text { table ( } 0.3610) \text {, so it can be concluded that there is a significant } \\
\text { effect of the playing method on the dribble ability of the game. } \\
\text { football students of class VIII SMP Private Budi Agung Medan. }\end{array}$ \\
\hline
\end{tabular}

Corresponding address: Jl. Alumunium Raya No 77 Medan, Indonesia

ISSN 2685-6514 (online)

Email : alanalfiansyahputra03@gmail.com

ISSN 2477-331X (print)

DOI : $10.33369 / \mathrm{jk} . \mathrm{v} 4 \mathrm{i} 2.12566$

\section{INTRODUCTION}

Teacher performance in the teaching-learning process is one of the most important parts in supporting the creation of an effective learning process, especially in building disciplinary attitudes and the quality of student learning. However, when the teacher fails to minimize deviant behavior by students, it often makes the teacher reluctant to return to solving all kinds of problems to return to the state they should be. This of course should be avoided as much as possible by every educator. Therefore, teachers are stated to be highly dedicated, if they are able to face and solve every student problem that occurs in the school environment, to create a good and correct teaching and learning atmosphere.

Apart from teachers, the facilities and infrastructure available in the school environment also play an equally important role. Facilities and 
infrastructure in the field of physical education will certainly greatly support the implementation of a comprehensive and sustainable learning process. Although it is not uncommon to find cases where the facilities and infrastructure have been completed, another problem arises, namely the lack of human resources (teachers) who master the use of facilities and infrastructure in a professional manner.

Broadly speaking, of course there are many things that influence the creation of a conducive teaching and learning environment, starting from the ability of the teaching staff (teachers) to the availability of qualified facilities and infrastructure. If these factors have been met, then the learning process will certainly run well too, which in turn will create a more varied teaching-learning atmosphere to stimulate students' interest in carrying out various forms of activities in physical education, health, and sports.

Mukholid (2007) states that "in the game of football there are several basic techniques which are very closely related to one another in a soccer game. Various problems are seen in the implementation of each stage (phase) in the dribble of the soccer game, and each student shows an error. The movements are very diverse, both in the preparation phase, the implementation phase of the motion, and the final stance phase. In addition, the level of teacher creativity in learning dribbling soccer games is still relatively low. Where teachers still apply monotonous or non-varied types of learning. This causes students to feel bored, which most students are in the age group who are in the adolescent phase. Where in this phase, a child likes activities that are complex and challenging.
According to Soewarno (2001) dribbling has principles, namely that the ball must always be controlled (not too far / close to the feet), the ball must be protected (use the right method and foot, according to the circumstances and position of the opponent), and eye view. on the ball, field and opponents. According to Luxbacher (2004) as for the implementation process of leading football, consisting of:

a. Preparation

- Posture in an upright and relaxed state.

- The ball is near the outside of one leg (strongest leg).

- Head position to the front.

b. Motion Execution

- Attention is focused on the direction of the ball.

- Kick the ball using the outer leg as much as $30 \mathrm{~cm}$

- Approach the ball until it touches one foot again.

c. Follow Through

- The position of the head occasionally sees the position of the ball that is rolling.

- Return to the ball with one leg.

- Position the body back to its original state (upright and relaxed).

There are several things that teachers can do in overcoming this problem, one of which is by using the playing method. Of course, in this case what is meant is a playing approach so that students can easily understand and practice the basic techniques of dribbling soccer games. The essence of learning the playing method The basic concept of the playing method According to Wina Sanjaya (2009) the learning method can be interpreted as a starting point or our 
point of view towards the learning process.

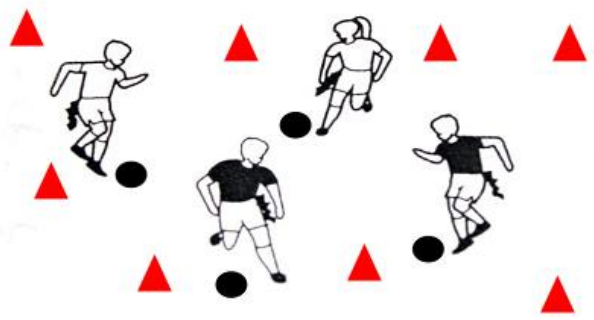

Figure 1. The Tails Collecting Game

The rules of the game above are a) ask each student to make a tail with a long leaf, tuck the long leaf in the back as a tail, b) on cue from the teacher, Students scramble each other for tails, to collect as many tails as possible, after the tail is obtained, throw it out of the playing arena, c) the player who has lost the tail must leave the arena, During seizing the tail, or dodging, the ball must remain in control of the foot, d) the winner of this game is the player who can keep the tail and the ball still in possession until the end of the game.

The solution given to students is in the form of a playing method in such a way that it resembles the dribble activity of an actual soccer game. This playing method is considered to be able to influence the overall level of students' understanding of the dribble material for soccer games. Because this playing method contains some simple movements that are commonly done in dribble material for soccer games. Thus, the researcher felt the need to overcome the problem that occurred, namely the effect of the playing method on the dribble ability of the soccer game.

\section{METHODS}

This study uses one group only. In this study, the cause variable is the playing method, and the consequent variable is the dribble skill of the soccer game. So, this study looks for whether there is a significant effect of playing methods on the dribbling ability of the soccer game. According to Sugiyono (2013: 110), the One Group Pretest and Posttest Design method is a research design with a pretest before being given treatment, thus the treatment results can be known to be more accurate because it can compare with the situation before being given treatment. The population and sample studied in this study were 30 students of class VIII SMP Private Budi Agung Medan. To determine the effect of squat training on increasing leg muscle power, the ability to dribble the ball was measured using a soccer skill test according to Nurhasan (2007: 212).

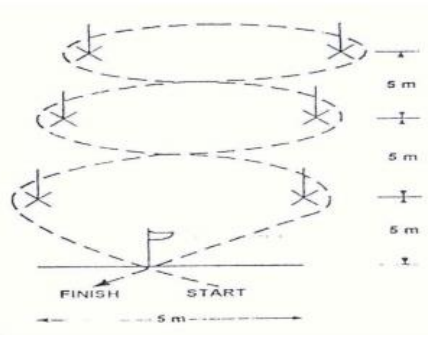

Figure 2. Soccer Dribble Test

Table 1. Boundary Dribble Norms Limitation

\begin{tabular}{llc}
\hline No & Interval Formula & Category \\
\hline 1 & $\mathrm{X}<\mathrm{M}-1,5 \mathrm{SD}$ & Very Good \\
2 & $\mathrm{M}-1,5 \mathrm{SD} \leq \mathrm{X}<$ & Good \\
& $\mathrm{M}-0,5 \mathrm{SD}$ & \\
3 & $\mathrm{M}-0,5 \mathrm{SD} \leq \mathrm{X}<$ & Enough \\
& $\mathrm{M}+0,5 \mathrm{SD}$ & \\
4 & $\mathrm{M}+0,5 \mathrm{SD} \leq \mathrm{X}<$ & Less \\
& $\mathrm{M}+1 \mathrm{SD}$ & \\
5 & $\mathrm{X} \geq \mathrm{M}+1,5 \mathrm{SD}$ & Very Less \\
\hline
\end{tabular}


Hypothesis testing is carried out in several stages, namely (1) Normality Test, (2) Homogeneity Test, and (3) Hypothesis Test using the t-test (Iwan Saputra, Umar Sapriadi, 2020). At the beginning of the study, before giving the treatment a preliminary test was carried out. To test the difference between the two means of the initial test result data and the final test result data, the researcher used the t-test analysis technique. The calculation of the t-test uses the help of the statistical application SPSS statistics for windows version 24.0 with the paired sample t-test method. Paired sample t-test is a different test of two paired samples, namely the same subject but experiencing different treatment (Samosir et al, 2020).

To determine the significance or presence or absence of dribbling skills using the playing method after the initial test (pretest) and before the final test (posttest), if the probability $<0.05$ at the $5 \%$ significance level, there is a significant effect of the training method on the dribble ability of the game. football with the null hypothesis (Ho) is rejected and the alternative hypothesis is accepted (Ha).

\section{RESULT}

This study was used to determine the effect of the playing method on the dribble ability of the soccer game, soccer training, eighth grade students of Budi Agung Private Junior High School, Medan. This research begins with a pretest, then continues with the provision of treatment and ends with a post test. The description of the results of the pre test and post test can be seen in table 2 below:
Table 2. Description of Pre Test and Post Test Data

\begin{tabular}{ccccc}
\hline & Mean & SD & MAX & MIN \\
\hline Pre & 20.0293 & 3.46127 & 28.00 & 15.60 \\
Test & & & & \\
\hline Post & 20.3860 & 3.32867 & 28.00 & 16.65 \\
Test & & & & \\
\hline
\end{tabular}

Based on table 2, it can be seen that the average value of the pre-test data is smaller than the post-test data, which is 20.0293 to 20.3860 , for the magnitude of the standard deviation of pre-test 3.46127 and post-test 3.32867, for the maximum value obtained in pre-test. 28.00 test is the same as the post test 28.00 , while the minimum pre-test score is 15.60 while the post test is 16.65 . From these results, it can be concluded that providing a playing method with a sample of 30 students has an effect on the ability to lead soccer games.

Tabel 3. Paired Samples Test

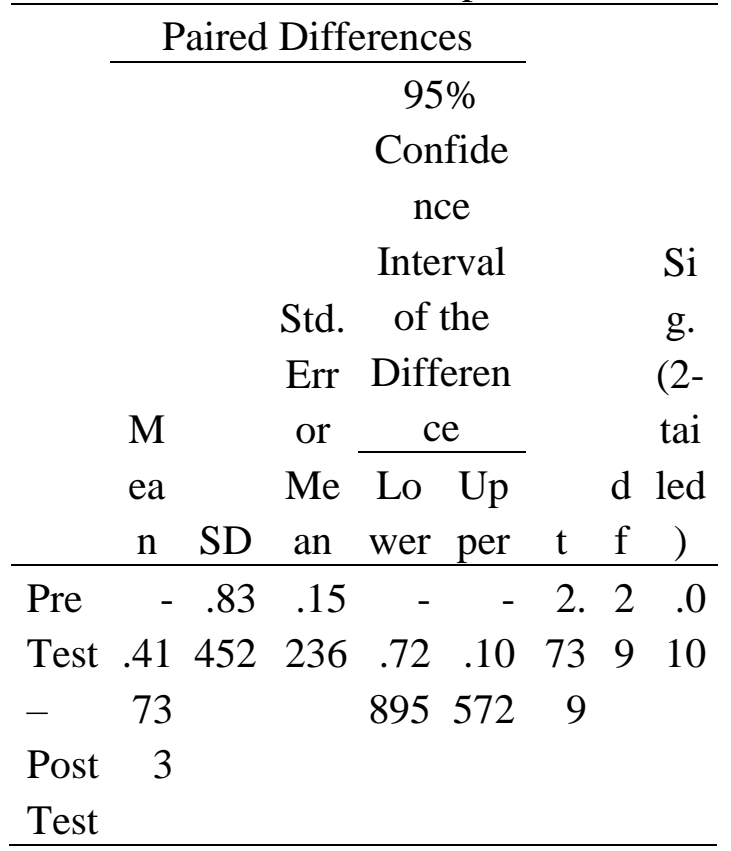


The data for calculating the results of the t-test can be seen in table 4.From the presentation of the data above, it can be seen that the significance (0.010) is smaller than 0.05 and the t-test result (2.739) is greater than the t-table (0.3610), so that It can be concluded that there is a significant effect of the playing method on the dribble ability of the students of class VIII SMP Private Budi Agung Medan.

\section{DISCUSSION}

Playing and children is one of the things that cannot be separated. Play activities are carried out by children and play activities are carried out by children and children's activities always show play activities. Play and children are closely related, so that one of the principles of learning in elementary schools is playing and learning, especially playing in improving dribbling skills.

In line with that, Dimyati and Mudjiono (2015) argue that learning is a complex activity, learning outcomes are in the form of capabilities, after learning people have skills, knowledge, attitudes and values. The emergence of these capabilities is from stimulation that comes from the environment and cognitive processes carried out by learning.

Playing is inherent in children which has become a necessity for adults. Playing with friends will make students sensitive to the needs and values of others, manage emotions, foster an attitude of sharing with others, cooperate with each other and develop motivation.

Another opinion, apart from using the teaching play method according to Guthrie in Rusli Lutan
(1998), explains that skills can be obtained through repetition (drill). Repetition can be useful for expediting students to do a greater number of correct and correct responses. Mastery of a skill or strengthening of new skills will be obtained through repetition where each repetition phase develops a compact stimulus-response relationship. Based on the above, in addition to using the playing method, the dribble ability of the soccer game can be obtained through the training method.

\section{CONCLUSION}

This study was used to determine the effect of the playing method on the dribble ability of the soccer game, soccer training, eighth grade students of Budi Agung Private Junior High School, Medan. The t-test is greater than the ttable, so it can be concluded that there is a significant effect of the playing method on the dribbling ability of the eighth grade students of Budi Agung Private Junior High School, Medan.

\section{REFERENCES}

Agus Mukholid. (2007). Pendidikan Jasmani Olahraga dan Kesehatan. Jakarta timur: Yusdistira.

Agus Salim Samosir, Fajar Apollo Sinaga, Rika Nailuvar Sinaga, Deni Rahman, Marpaung, Asnita Novida Nababan, Roni Sinaga. (2020). Pengaruh Senam Aerobik Dan Suplementasi Bawang Putih Terhadap Penurunan Kadar Kolesterol Total Dan Trigliserida Wanita Penderita Obesitas. Sains Olahraga : Jurnal Ilmiah Ilmu Keolahragaan, 4(1): 1-12. Doi: https://doi.org/10.24114/so.v4i1.177 81.

Fauzi, F. (2016). Pengaruh Latihan Pliometrik Modiflkasi Terhadap Power Otot Tungkai Pada Olahraga Bolavoli. Jurnal Cakrawala 
Pendidikan,

2(2).

doi:https://doi.org/10.21831/cp.v2i2.

8584.

Karyono, T. (2016). Pengaruh Metode Latihan Dan Power Otot Tungkai Terhadap Kelincahan Bulutangkis. Jorpres (Jurnal Olahraga Prestasi), 12(1). doi:https://doi.org/10.21831/jorpres. v12i1.9496.

Kristina, P. C. (2018). KEMAMPUAN MENGGIRING BOLA (STUDI KORELASIONAL KECEPATAN DAN KELINCAHAN DENGAN KEMAMPUAN DRIBEL PADA PERMAINAN SEPAKBOLA SISWA SEKOLAH MENENGAH PERTAMA). Halaman Olahraga Nusantara (Jurnal Ilmu Keolahragaan), 1(1).

Luxbacher, Joseph. (2004). Sepakbola: Langkah langkah menuju sukses. Penerjemah Agus Wibawa. Ed.2 cet.4 Jakarta: PT. Raja Grafinda Persada.

Mudjiono, D. \&. (2015). Belajar dan Pembelajaran. Jakarta: Rineka Cipta.

Nurhasan. (2007). Ilmu Kesehatan Olahraga. Bandung: FPOK UPI.

Putri, D. S., \& Yarmani, Y. (2019). STUDI KEMAMPUAN SLALOM DRIBBLING DAN LONG PASSING PADA KLUB SEPAKBOLA WANITA DI KOTA BENGKULU. Kinestetik: Jurnal Ilmiah Pendidikan Jasmani, 3(2), 183-192.

Soewarno. (2001). Sepakbola: Gerakan Dasar dan Teknik Dasar. Yogyakarta. FIK UNY.

Sudijono Anas. (2009) Pengantar Statistik Pendidikan, Jakarta : PT. Raja Grafindo Persada

Sugiyono. (2013). Metode Penelitian Pendidikan Pendekatan Kuantitatif, Kualitatif, dan R\&D. Bandung: Alfabeta.

Sulistio, D. (2019). Analisis Kemampuan Teknik Dasar Passing, Dribbling, Dan Shooting Pada Pemain Sepak Bola SSB Putra U 10-12 Tahun Di Kabupaten Kaur. Kinestetik: Jurnal
Ilmiah Pendidikan Jasmani, 3(2), 241-248.

Wina Sanjaya. (2009). Penelitian Tindakan Kelas. Jakarta : Kencana.

Yarmani, Y. (2020). Pengaruh Latihan Lari Zig-Zag Menggunakan Beban Terhadap Peningkatan Keterampilan Dribbling dalam Permainan Sepak Bola Pada Siswa Ekstrakurikuler SMA Negeri 4 Seluma. SPORT GYMNASTICS: Jurnal Ilmiah Pendidikan Jasmani, 1(1), 9-15. 